\title{
Hanna Suchocka*
}

Adam Mickiewicz University in Poznan

\section{ABOUT EUROPEAN STANDARDS CONCERNING THE APPOINTMENT OF JUDGES OF COMMON COURTS (BASED ON THE EXPERIENCE OF THE VENICE COMMISSION)**}

DOI: http://dx.doi.org/10.12775/TSP-W.2018.003

Date of receipt: 26.06 .2018

Date of acceptance:15.08.2018

Summary. The process of restoring a democratic judiciary in the countries of Central and Eastern Europe has proved to be an extremely difficult and lengthy one. An important role in the process of searching for these solutions and ,discovering" European standards has been played by the Venice Commission from the very beginning of its existence. It should also be noted that the legal standards concerning the judiciary in the area of the Council of Europe were significantly convergent with the standards formulated by the European Union, as demonstrated by the subsequent EU adhesion processes.

Keywords: appointment of judges; Venice Commission; European standards; judiciary.

Wokół standardów europejskich dotyczących powoływania sędziów sądów (z doświadczeń Komisji Weneckiej). Nie ulega jednak wątpliwości, że proces przywracania demokratycznego sądownictwa w państwach Europy Środkowej i Wschod-

* Hanna Suchocka - dr hab., prof. nadzw. UAM, Division of Constitutional Law, Faculty of Law and Administration, Adam Mickiewicz University in Poznan, e-mail: hansuc@amu.edu.pl; ORCID: 0000-0002-6218-1893.

*** This article is an extended and revised version of paper, which was presented in the international conference „Potentia non est nisi da bonum” in Toruń, November 16, 2018. 
niej okazał się procesem niezwykle trudnym i długotrwałym. Istotną rolę w procesie poszukiwania tych rozwiązań i „odkrywania” standardów europejskich odgrywała od samego początku swojego istnienia Komisja Wenecka. Zaznaczyć też należy, że standardy prawne dotyczące sądownictwa w obszarze Rady Europy były w istotny sposób zbieżne ze standardami formułowanymi przez Unię Europejską, co wykazały późniejsze procesy adhezyjne do UE.

Słowa kluczowe: powoływanie sędziów; Komisja Wenecka; standardy europejskie; sądownictwo.

Since 1990, countries liberating themselves from the domination of the Soviet system have been striving to become members of the Council of Europe. However, starting the procedure for accession to the Council of Europe required a number of conditions to be met in order to satisfy the criteria on which the Council of Europe are built. The statute of the Council of Europe clearly states that: „Each member of the Council of Europe recognizes the principle of the rule of law and the principle that all persons under its jurisdiction enjoy human rights and fundamental liberties; it must also cooperate sincerely and substantially to achieve the Council's objective as set out in Chapter I. The Europe formed around the Council of Europe and the European Community has been setting standards with human dignity as a guiding principle. The other part of Europe (the eastern one) was focused on collective rights and not on liberties and rights of the individual. At this point, one ought to agree with the statement that the Council of Europe is not a good in itself. It is so only if it meets the objectives for which it was established, i.e., first and foremost, it ensures the protection of the individual through a whole system of rights and liberties and their guarantees rooted in the rule of law, one of the key components of which is the principle of an independent judiciary. Therefore, one of the most important requirements and challenges faced by the countries applying to the Council of Europe was to carry out, in a very vaguely defined manner, a „reform of the judiciary”. At the same time, it was a commitment to the constant application of certain principles and procedures.

The organization of the judiciary in the previous system was based on the principle of unity of power. While this concept could somehow explain the relations between the legislative and executive authorities, the doctrinal justification for placing the judiciary in a system of unity of authorities, strengthened by the leading role of one political party, was quite risky. The political and systemic structure based on the unity of power and the leading role of the party had a sig- 
nificant impact on the legal and real autonomy of the judiciary and the independence of the judges ${ }^{1}$.

For this reason, the principle of separation of powers appeared to be the only possible organizational principle defining the relationship between the judiciary and the legislative and executive powers, laying the foundations to guarantee the autonomy and independence of the judiciary. There is a consensus that the specific instruments that the authorities can use towards each other for the purpose of mutual moderating and balancing, including those guaranteeing the independence of the judiciary, may vary from country to country. This principle presupposes a specific way of defining the relations between the judiciary and the other authorities, which was clearly emphasized in the judgment of the Polish Constitutional Tribunal. The Tribunal stated that different forms of interaction and cooperation are possible in relations between the legislative and executive authorities, and that there is also an area in which the competences of bodies belonging to both authorities ,intersect” or „overlap”. By contrast, the relationship between the judiciary and the other authorities has to be based on the principle of ,separation"2.

In the process of constitutional works in the 1990s, there was no assumption of a fundamental tension between the executive and the judiciary authorities. It was believed that the classic formula of division of powers, guaranteeing the most important aspect of the system, i.e. the principle of the independence and autonomy of the judiciary, was sufficient. One could think that the principle is obvious and irrefutable that ,the pressure of the executive on the courts has always been treated as pathology, and through the constitutionalization of the principle of independence of the judiciary from other authorities, it is not only reprehensible, but also violates the constitution" ${ }^{3}$. However, such an understanding of the principle of the separation of powers is now being increasingly denied in political practice. Hence, perhaps there is a need for a more detailed and precise definition of this principle in the Constitution itself. This problem was articulated in the opinion of the Venice Commission on the amendments to the Serbian Constitution of 2018. When analyzing the proposed amendments to the Constitution,

${ }^{1}$ Cf: H. Suchocka, L. Kański, Zmiany konstytucyjnej regulacji sądownictwa i prokuratury dokonane w 1989 r., „Państwo i Prawo” 1991 n. 1, p 18.

2 Judgment of the Constitutional Tribunal K.8/99. See also R. Piotrowski, Sędziowie i granice wtadzy demokratycznej w świetle Konstytucji RP, ,Ruch Prawniczy, Ekonomiczny i Socjologiczny" 2018, n. 1, p. 217.

${ }^{3}$ E. Lętowska, J. Lętowski, Co wynika dla sądów z konstytucyjnej zasady podziału władz, [in:] Konstytucja i gwarancje jej przestrzegania. Księga pamiq̨tkowa ku czci prof. J. Zakrzewskiej, Warszawa 1996, p. 390. 
the Commission referred to Article 4 of the current Constitution, which regulates the principle of separation of powers, in relation to which no amendments have been made. It now reads as follows: „The system of government is based on the division of powers between the legislative, the executive and the judiciary". This is the expression of a general principle. However, the content of Article 4 is not limited thereto and also refers to the issue of ensuring the balance of power in the following words: „The relationship between the three authorities is based on balance and mutual control". There is no doubt that the principle of balance of powers is an important element of the principle of separation. In this case, however, the Commission had reservations about the phrase: „mutual control”. The Commission emphasized that the term ,mutual control” may give rise to misinterpretation of the role of other authorities, and in particular the executive power, in relation to the courts and may ultimately lead to a political control over the judiciary. For this reason, it recommended that the term ,mutual control" be deleted from the text of the Constitution, leaving the wording that these relations are based on the rule of „checks and balances”, which would remove the basis for a possible political over-interpretation in mutual relations ${ }^{4}$.

The main objective of court reform was to ensure the full autonomy of courts and the independence of judges in adjudication, in order to guarantee their fundamental function, which is to ensure the impartial administration of justice and the protection of the rights of the individual. As R. Piotrowski emphasizes, the systemic sense of the judiciary power lies in the fact that it is the guardian of human dignity, the guardian of universal and timeless values. Sometimes the parliamentary majority forgets about these values because of political interests, or does not wish to think about them in the legislative process. The judiciary, independent of the parliamentary majority, has the ability to make corrections for the sake of the values that the human rights culture considers to be superior to any authority, including the authority with electoral legitimacy ${ }^{5}$.

As a rule, compliance of the internal solutions of sovereign states with European standards is achieved in three stages: the first stage is a change in the constitution, the second one - changes in ordinary legislation, and the third stage is the implementation system. The first years of transformation, not only in Poland, can be described as a time of searching, both in the systems of other states and in one's own internal system, for solutions best suited to the implementation of the general principle of independence of the judiciary. Searching for appropriate

${ }^{4}$ Opinion regarding Draft amendments to the Serbian Constitution in the field of the judiciary CDL-AD (2018)011.

${ }^{5}$ R. Piotrowski, op. cit., p. 217. 
solutions, countries referred to their own democratic traditions to the extent that they were rooted in the European legal culture. The choice of solutions was quite narrow. There are a number of principles in Europe's legal heritage that must be respected by all democratic countries in terms of the place of the judiciary and the status of judges, a tradition that dates back to Magna Carta ${ }^{6}$. Some solutions may vary in terms of detailed organization or more technical guarantees of independence, but not in terms of key principles.

And in this context of searching for appropriate solutions common to individual countries and rooted in the European legal heritage, the concept of the „European standard" has emerged. There is no doubt, however, that the process of restoring a democratic judiciary in the countries of Central and Eastern Europe has proved to be an extremely difficult and lengthy one. An important role in the process of searching for these solutions and ,discovering" European standards has been played by the Venice Commission from the very beginning of its existence. It should also be noted that the legal standards concerning the judiciary in the area of the Council of Europe were significantly convergent with the standards formulated by the European Union, as demonstrated by the subsequent EU adhesion processes ${ }^{7}$.

II. When undertaking the process of reform of the judiciary, it was recognized that the basic principles concerning the place of courts and defining the role of judges should be regulated in the constitution ${ }^{8}$. Such a method of regulation was indicated as optimal in Opinion No. 1 (2001) section 16 of the Consultative Council of European Judges (CCJE) on standards of independence of the judiciary and the irremovability of judges in the following words: „The basic principles of the status of judges should be regulated in the national law at the highest (constitutional) level and the detailed principles (rules) - at least at the statutory level". The regulation of judicial rules at the constitutional level was also recommended by the Venice Commission ${ }^{9}$.

${ }^{6}$ The British Prime Minister commented on the celebration of the 800th anniversary of Magna Carta: „800 years ago King John sealed a document that changed the world. (...) The boundaries of executive power have been defined, access to court guaranteed, the belief that there is such a thing as a rule of law established".

${ }^{7}$ Por. Monitoring the EU Accession Process: Judicial Independence, Open Society Institute, Budapest 2001.

8 The form of constitutional regulation was also indicated in the Recommendation of the Committee of Ministers of the Council of Europe, Recommendation (94)12 of the Committee of Ministers on the Independence, Efficiency and Role of Judges. (Principle I.2.a): „The independence of judges should be guaranteed pursuant to the provisions of the Convention and constitutional principles, for example by inserting specific provisions in the constitutions

${ }^{9}$ CDL-AD(2010)004, Report on the Independence of the Judicial System Part I: The Independence of Judges. 
Although the method of constitutional regulation concerning the judiciary, as has already been pointed out, varies from country to country, a characteristic tendency common to all post-communist countries is a more detailed constitutional regulation than can be observed in the so-called stabilized democracies. As a rule, in the so-called ,new democracies" the solutions that are regulated at the level of ordinary legislation in stable democracies have been transferred to the level of constitutional regulation. This was mainly owing to two factors: 1 . recognizing the constitution as the highest legal act in the system of sources of law, and the associated rigidity of the constitution, which was supposed to act as a protection against possible changes in the rules concerning the judiciary through an ordinary law in the conditions of a changing parliamentary majority; 2. lack of stable democratic mechanisms, as well as constitutional customs, which were only to be shaped, also as a result of the constitutionalization of certain principles. Such a legislative approach was intended to play an important role as a guarantee against hasty changes and the weakening of the democratic standards which had been introduced.

Poland was the first country in Central and Eastern Europe to make fundamental changes in the judiciary. As a result of the amendment to the Constitution, as early as in April 1989, Article 60 of the Constitution was amended to read. 1. Judges are appointed by the President, at the request of the National Council of the Judiciary, 2) Judges are irremovable, save in cases specified in the Act. Details have been referred to the statutory regulation. Changes have also been made to the regulations on the Supreme Court. Among other things, the wording referring to the appointment of judges of the Supreme Court for a period of 5 years has been removed (Article 61, section 3). There is no doubt that the changes introduced by the April amendment established the basis for the status of judges, which brought Polish solutions closer to democratic European standards.

As a result of these constitutional changes, amendments were subsequently made to the Act on the system of courts on 20 December 1989, which developed and detailed the constitutional principles. Significant changes of a systemic nature have been introduced to the Act regarding the Supreme Court. These include, among others: a) removal of formulations concerning political tasks from the statutory principles of the implementation of justice, b) depriving the minister of justice of the right to dismiss judges, also in situations provided for in the Act, such as age or health reasons, c) removal of the compromised provision owing to its political use, i.e. the possibility to dismiss a judge who does not give a proper guarantee of performance of duties ${ }^{10}$. The latter provision practically

${ }^{10}$ H. Suchocka, L. Kański, op. cit., pp. 21-23; H. Suchocka, The separation of powers in the Polish Constitution, „Review of Central and East European Law” 2000, n. 3, pp. 338-340. 
eliminated the principle of the independence of the judge, as the final oracle was a political institution. Thus, the changes made in the Polish law covered areas which were key to freeing the judiciary from politicization since they concerned the way in which judges were appointed: - the stability of the position of the judge, the apolitical nature of judges,and the impartiality of the judge. These were, therefore, the areas which, according to the Venice Commission, are also crucial for ensuring the independence of the third authority ${ }^{11}$.

3. In this catalogue of problems, the issue of the adoption of an appropriate system for the appointment of judges, ensuring the independence of the third authority, became one of the most important challenges for the countries undergoing transformation. It was therefore no coincidence that, after the issuance of many individual country-specific opinions on judicial reform, the first comprehensive report of the Venice Commission in the area of judicial power was the report on the appointment of judges ${ }^{12}$. An important premise underlying the report was the search for a system that would allow for an effective de-politicization of the process of appointing judges by choosing the optimal way of conducting this procedure in the conditions of a particular country. This report should undoubtedly be seen as a first attempt to identify possible solutions falling within the general concept of the European standard. Notably, the Commission has recognized and underlined the importance of the diversity of systems, pointing out that there is no single ,non-political" model for appointing judges which could be regarded as ideal for implementing the principle of separation of powers in each country. Specific solutions will largely depend on the internal situation of a given state and its democratic legal tradition. Despite the fact that it does not propose a single model, the Commission indicates specific solutions (institutions, principles), which must be taken into account in the process of searching for a system of appointing judges free from political influence and these can be included in the European standard.

In this respect, an important negative element is also the ,undemocratic tradition" which shaped the systems of relations between the judiciary and other authorities for more than forty years of the past system. As a result of this aspect, specific solutions are not set in a vacuum. Therefore, some of the ways of appointing judges that exist in countries with a stable democracy and established

${ }^{11}$ CDL-AD(2010)004, Report on the Independence of the Judicial System Part I: The Independence of Judges,

12 Judicial appointments (CDL-AD (2007)028). This report was the Venice Commission's contribution to the Opinion No. 10 of the Consultative Council of European Judges (CCJE) on the structure and role of judicial councils. 
democratic and constitutional customs do not pose a threat of the politicization of the appointment system, such as the appointment of judges by the government (the Minister of Justice). In such systems, the appointment of judges by the Minister of Justice does not give rise to any fundamental doubts from the point of view of the principle of independence of the judge. This is because the mechanisms of legal culture and tradition that have developed over a long period of time limit the executive power in its relations with the judiciary ${ }^{13}$. These mechanisms are not working strongly enough in the so-called new democracies, where for several dozen years the political power influenced the appointment of judges. Therefore, in this cultural context, the way in which the government (Minister of Justice) is involved in the appointment of judges raises serious concerns that it will not be an effective guarantee of de-politicization of appointments and, as a consequence, guarantee of judicial independence. In such a situation, different instruments and thus different systems of judicial appointments are needed to free judges from the influence of the executive power.

4. The discussion concerning the Superior Council of the Magistracy has therefore become one of the key issues ${ }^{14}$. The establishment of such councils has become a kind of ,sign of the times”. Since the early 1990s, such councils have been founded in an increasing number of states, also in the so-called traditional democracies. There is a widespread belief that such a council can best guarantee the apolitical nature of judicial appointments ${ }^{15}$. The discussion that took place in the Venice Commission about the need for such councils and their role is a testimony to the evolution of the situation and the evolution of viewpoints related to the search for optimal guarantees for the independence of judges. Through the prism of the circumstances existing in many traditional democracies where judicial councils did not exist, the Commission did not initially express such a strong position on the need for their appointment. The Commission's position in this respect was rather conducive to the establishment of councils, but very cautious. In its opinion on the 1998 Constitution amendments in Albania, it stated that

${ }^{13}$ Report on „Judicial appointments” (CDL-AD (2007)028).

14 The names of such councils vary from country to country, e.g. High Council of Justice, Supreme Judicial Council, High Council of the Judiciary, Superior Council of Magistrates, National Council of the Judiciary, Polish Krajowa Rada Sądownictwa [National Council of the Judiciary]. For the sake of simplicity, I will be using the general name of the Superior Council of the Magistracy (SJC).

15 These already exist in the following countries: Albania, Andorra, Belgium, Bulgaria, Cyprus, Georgia, Greece, Denmark, Estonia, Finland, France, Iceland, Ireland, Italy, Lithuania, Moldova, the Netherlands, Norway, Poland, Portugal, Romania, Russia, Slovakia, Slovenia, the Former Yugoslav Republic of Macedonia, Ukraine, Turkey. 
many European countries are now introducing politically neutral supreme judicial councils or similar bodies, sometimes at the constitutional level, as an effective instrument for the observance of fundamental democratic principles, and in particular the autonomy and independence of the judiciary and its role in guaranteeing fundamental rights and liberties. However, notwithstanding the generally positive statement on the appointment of councils, the Commission made it clear that ,it cannot be considered as a principle that a democratic state has to create a Superior Council of the Magistracy"16. Thus, in the second half of the 1990s, the establishment of a judicial council was not, in the opinion of the Venice Commission, an absolute ,standard" to which all countries have to refer. The Commission took the view that as long as an independent judiciary could be otherwise ensured in a given state, there was no need to set up such a council. Therefore, the absence of a council does not signify that such a solution is contrary to a European standard if the independence of the judiciary and its liberation from political influence is otherwise ensured.

However, because of the burden of the post-communist heritage, the Commission decided that although the appointment of councils is not treated as a mandatory European standard, it is still recommended.

This position has been evolving in relation to the assessment of the situation in subsequent countries that have undertaken a judicial reform. In its successive opinions, the Commission has already set out a clear opinion, in fact pointing out the need to set up such a body, equipped with a feature of autonomy or even independence.

This position was clearly expressed in the Commission's 2010 report on judicial independence, which states that, while recognizing and respecting the diversity of existing legal systems rooted in Europe's rich legal culture, it is recommended that countries that have not yet done so consider establishing an independent judicial council or a similar body, which would have a pluralistic composition, but which would be composed essentially or even a predominantly of judges, elected by the judiciary circles (their peers) ${ }^{17}$.

In this context, it raises the question of whether the appointment of judicial councils should be regarded as a European standard which has to be respected by all Member States. I believe that, in view of the widespread adoption of this institution, it can be regarded as a European standard. However, the essence of

16 Opinion on the subject: Recent Amendments to the Law on Major Constitutional provisions of the Republic of Albania, CDL-INF(1998)009.

${ }^{17}$ CDL-AD(2010)004, Report on the Independence of the Judicial System Part I: The Independence of Judges, as well as CDL-AD(2013)018, Opinion on the balance of powers in the Constitution and the Legislation of the Principality of Monaco. 
such an institution is to guarantee what is an indisputable axiom, namely the principle of judicial autonomy and independence. In these circumstances, it is necessary to maintain the view that if it is possible to guarantee the manner in which a judge is appointed in a different way, the very lack of a council does not rule out the democratic nature of the state. Conversely, the mere existence of a council, if it is not free from political influence, cannot be considered a desirable European standard.

What is important, however, is that the council enjoys the attribute of autonomy. And this is an absolute European standard. Therefore, in countries where such councils are established, these have to be free from political influence. Thus, the mere establishment of a council is not a condition sufficient to recognize that the existing system provides guarantees for the de-politicization of courts. It is necessary that the council meets certain conditions justifying its establishment. Such conditions ought to include: the composition of the council, the way in which it is elected, the way in which decisions are taken, and the legal nature of the council's decisions. It is these elements that the Venice Commission analyses in each country.

This position has been very clearly set out in recent opinions of the Venice Commission in relation to changes in the Polish judiciary ${ }^{18}$ as well as in recent opinions concerning Serbia ${ }^{19}$ and Romania ${ }^{20}$, and also earlier in relation to the constitutional reform of the judiciary in Ukraine and Hungary.

$\mathrm{V}$. One of the main problems with regard to the appointment of the council is its composition and an election method which would ensure its autonomy. It is emphasized that the essence of this institution implies that it should be pluralistic in nature, i.e. it should not consist only of judges, in order not to create a judicial corporationism which is dangerous for the impartiality of judges. The council should maintain a balance between the representatives of judges and other institutions. However, even with such a pluralistic approach, the essential part and even the majority of the council should be judges elected by the judiciary itself. In this respect, the Commission refers to the stance expressed in Recommendation $\mathrm{CM} / \operatorname{Rec}(2010) 12$ stating in section 27 that: „Not less than half of the mem-

${ }^{18}$ Opinion on the draft acts regarding the National Council of the Judiciary, Supreme Court and common courts in Poland, CDL-AD(2017)031.

${ }^{19}$ Opinion on the draft amendments to the Constitution on the Judiciary in Serbia, CDL-AD (2018)011.

${ }^{20}$ Preliminary opinion on 3 draft acts in Romania: on the status of judges and prosecutors (Act No 303/2004), on the organization of the judiciary (Act No 304/2004), on the Supreme Council of Judges (No 317/2004), CDL-AD (2018)007. 
bers of such councils should be judges elected by their own circles at all levels of the judicial system with respect for pluralism inside the judiciary", recognizing it as a European standard ${ }^{21}$.

Taking this position into account, one can undoubtedly agree that the construction of the National Judicial Council, as provided for in the Polish Constitution in art. 187, is the optimal solution, corresponding to the European standard. This is because the Council consists of three categories of persons who are: 1) persons performing functions ex officio, i.e. President of the Supreme Court, Minister of Justice, President of the Supreme Administrative Court and a person appointed by the President of the Republic of Poland, 2) judges (15 members), 3) persons elected by parliament ( 4 members elected by the Sejm and 2 members elected by the Senate). Therefore, such a structure of the council established in the Constitution logically corresponded to the essence of the body which is the $\mathrm{NCJ}$, and in particular to ensuring its autonomy, apolitical nature, and pluralism. From the content and wording of Article 187, it is clear that only one category of council members (parliamentarians) is elected by parliament. On the other hand, the wording contained in section 2 , which refers to members elected from among judges of courts of different levels, clearly indicates the legislator's intention that the choice is made by the judicial circles. If it were to be otherwise, then the provision of the Constitution should contain wording concerning two categories of members elected by parliament, i.e. parliamentarians (MPs and senators) and judges. The listing of three separate categories of council members in three separate points of Article 187 means that they obtain their mandate from different sources (ex officio, election by the judicial community and parliamentary election). Such a system ensures balance and creates conditions for apolitical appointments ${ }^{22}$. There is no doubt that interpretation of the Constitution must be carried out in a holistic way, which entails that the meaning of the provisions of the Constitution is not determined in isolation from their mutual relationship. Since, in accordance with Article 8(1) of the Constitution, the Constitution is the supreme law, interpretative doubts should be resolved in favour of respect for the fundamental values and constitutional principles that determine the rules

${ }^{21}$ This was also reiterated in a recent opinion on Serbia. CDL-AD (2018)011 section 36.

22 A critical assessment of such a solution was found in the opinion of the Venice Commission on Polish acts CDL-AD(2017)031: ,The election of the 15 judicial members of the National Council of the Judiciary (the NCJ) by Parliament, in conjunction with the immediate replacement of the currently sitting members, will lead to a far reaching politicization of this body". The Venice Commission recommends that, instead, judicial members of the NCJ should be elected by their peers, as in the current Act. 
of systemic rationality ${ }^{23}$. Hence, the view that parliament can also elect judges is a contradiction of the interpretation based on a system of constitutional values.

The same stance was clearly expressed in the Venice Commission's opinion on the Romanian acts on changes to the judicial system, where it is stressed that the relevant provisions have to be interpreted not only in the way they are worded, but from the perspective of the overall effect that they may have on the independence, efficiency, and quality of the judiciary ${ }^{24}$.

With regard to the persons appointed by parliament, the Venice Commission was rather of the opinion that they should not be directly involved in politics. An advisable solution would be that they should not be active parliamentarians: members of parliament, or senators, but rather legal practitioners elected by parliament. However, it should be noted that the idea of not electing parliamentarians as members of the council was a suggestion rather than a binding guideline. Thus, while allowing parliamentarians to become members of the judicial council, the Commission is of the opinion that the de-politicization of such a body means that the so-called, ,parliamentary component" should be elected by a qualified majority, so that the ruling majority cannot fill all posts.

In this context, the Commission was critical of the amendment to the Serbian Constitution of 2018, which provides for the council to be composed of 10 members, 5 representing the judiciary and 5 elected by parliament. This solution has been assessed as very problematic because the composition and system of election of the council members allows for the actual dominance of the government representation. For this reason, the Commission has proposed several solutions to depoliticize the election, including the introduction of a proportional electoral system that would ensure that a parliamentary minority can elect members of the council, or granting the right to elect council members to bodies outside government influence, such as bar associations or faculties of law, or a third solution which would increase the number of judges elected by their own community ${ }^{25}$.

Concepts concerning the composition of judicial councils in various countries have evolved. Among other things, the view that a government representative in the person of the Minister of Justice should not be a part of the council has been becoming more and more common. Such a solution, for example, was proposed in the amendment to the Serbian Constitution of 2018. However, the Commission is not as uncompromising as it was in respect of the ban on the participation of representatives of the executive in the composition of the Judiciary Council, especially the Minister of Justice, expressing the view that the pres-

\footnotetext{
${ }^{23}$ R. Piotrowski, op. cit., p. 217.

${ }^{24}$ CDL-AD (2018)007.

${ }^{25}$ CDL-AD (2018) 011.
} 
ence of a minister in the Council cannot, as a rule, be considered as a solution that is contrary to the European standard. This is because the mere presence of a minister in the composition of the council does not violate the council's independence (of course, if the other components of the council are not politically appointed). Under certain circumstances the minister's participation may even be advisable, as it may facilitate dialogue between the various stakeholders involved in the system. However, this is possible under certain conditions, namely: (1) the Minister's participation must not increase the risk of the Judicial Council being dominated by a ruling majority, (2) the Minister is not allowed to vote or even take part in decisions concerning the transfer of judges and decisions concerning disciplinary proceedings against judges ${ }^{26}$.

It can therefore be concluded that the pluralistic nature of the council is the European standard, with at least half, or even better, a majority of judges elected by the judicial community, not excluding possible participation of the Minister of Justice in the council, but subject to the conditions set out above.

Another issue is the participation of civil society representatives in the composition of the judicial councils. The Romanian system provides for the participation of civil society representatives in the composition of the council. However, their active participation in the composition of the council is limited. They can participate in plenary meetings, but cannot vote. The role of these representatives is essentially to ,inform and consult civil society organizations on the work of the council and how the council should work to improve the functioning of the judicial bodies; and to monitor the council's commitments to transparency, as well as public access to information and petitions from the public" ${ }^{27}$. The Commission is critical of the passive role of these representatives, assuming that the limited role attributed to the representatives of society in the work of the judicial council does not seem to be an appropriate solution. However, there is still no standard for the dismissal of members of judicial councils. Rather, the prevailing position is in favour of the impossibility of dismissal of individual members due to the council's independence ${ }^{28}$.

${ }^{26}$ CDL-AD (2018)011, as well as: Joint Opinion on the Draft Law on the Judicial System and the Status of Judges of Ukraine (CDL-AD(2010)003); Opinion on recent amendments to the law on major constitutional provisions of the Republic of Albania (CDL-INF(1998)009); Report on Judicial Appointments by the Venice Commission (CDL-AD(2007)028); Interim Opinion on Constitutional Reforms in the Republic of Armenia (CDL-AD(2004)044); Opinion on the reform of the judiciary in Bulgaria (CDL-INF(1999)005).

${ }^{27}$ CDL-AD (2018)007.

${ }^{28}$ In the Commission's view, a person elected to an important position such as membership of a judicial Council should not be subject to recall merely because the electorate do not agree with the decisions which are made. It should be the duty of persons elected to such positions to bring 
Controversial solutions have been proposed in the draft amendments to the Serbian Constitution of 2018. It is expected that if the council is unable to make a decision within 30 days (without specifying the nature of the decision), the council will be dissolved. As the council is composed of 10 members, 5 judges, and 5 persons of political choice, it is always possible to block a decision on political grounds, resulting in the resignation of the council as a whole. The Commission considered this to be unacceptable in view of the autonomous status of the council. Moreover, it has been stressed that the members of the council also have an independent status and therefore cannot be dismissed ,en masse” for the sole reason that one of the council members, perhaps for political reasons, is not involved in the council's decision-making process. In recent times, therefore, there has been a dangerous tendency in many countries to formally introduce the judicial council into the political system, in accordance with European standards, while, on the other hand, by adopting detailed solutions concerning the political composition and decision-making methods, the autonomous nature of the council and thus the objective for which it was established, i.e. guaranteeing the independence of the judiciary, is in fact being undermined. It is therefore difficult to consider such solutions as meeting European standards.

VI. In this context, it seems reasonable to give some attention to the specific solutions introduced in Hungary following the adoption of the new Hungarian constitution of 18 April 2011. The new constitution contained only a very general framework for the functioning of the judiciary, leaving the details of the organization and administration of the courts to be regulated by a specific form of cardinal acts. According to such a legislative concept, the judicial council, already existing in the political system, ceased to be a constitutional institution. This raised legal doubts as to its future existence and character ${ }^{29}$.

However, the regulations concerning the judicial council were included in the new CLXI Act of 28 November 2011, which provides for the existence of two bodies: the President of the National Judicial Office (NJO) and the National Council of the Judiciary (NJC) ${ }^{30}$. In the light of new solutions, the key decision-

their own independent judgement to bear on the important decisions the SCM has to deal with without having to anticipate a possible recall. Opinion on amendments to the Romanian Constitution CDL-AD (2014)010.

${ }^{29}$ Opinion of the Venice Commission „on the new Constitution of Hungary” CDL$\mathrm{AD}(2011) 016$.

${ }^{30}$ Act CLXI of 2011 on the Organization and Administration of Courts of Hungary z 2011, see: Opinion of the Venice Commission on the „Act CLXII of 2011 on the Legal Status and Remuneration of Judges and Act CLXI of 2011 on the Organization and Administration of Courts of 
making body has become a single-member body, which is the president of the NJO. This is because the office itself, managed by the president, does not have any real power and has been reduced to an agency that helps the president. It is up to the president to exercise all the administrative power previously held by the judicial council. In this context, too, the role of the judicial council itself has been extremely limited. In fact, since 1 January 2012, the judicial council has been replaced by a single-member body, which is the president of the Judges' Office.

This solution has been severely criticized by the Venice Commission since it does not fall within the framework of European standards and is outside the framework of the separation of powers. The president of the NJO is elected by parliament for 9 years. His mandate may be extended. He is in practical terms without responsibility and has not been included in the constitutional system of checks and balances. The role of the president of the office, given his remit, is more reminiscent of the role of the Minister of Justice in a system in which he had an extremely strong political power in relation to the courts and judges. Particular criticism has been levelled at his right to transfer cases to another court. The distribution of cases is one of the crucial elements for the impartiality of the courts. The Venice Commission concluded that in order to prevent the risk of abuse of power by a single-member body such as the NJO president, and to bring the legal regulations into compliance with Article 6 ECHR, the Hungarian authorities should use other mechanisms concerning case allocation. Court presidents and the president of the NJO should have no discretionary power to decide which cases should be transferred or to select the ,sending” or ,receiving" courts ${ }^{31}$.

The Commission proposed to strengthen the role of the judicial council as a monitoring body ${ }^{32}$. However, these opinions have not been taken into account and the position of the president of the NJO has been further strengthened as a result of the so-called fourth amendment to the 2013 Constitution. (Article 14) when this body was elevated to constitutional level ${ }^{33}$, while the judicial council was not mentioned in the Constitution at all. These solutions undoubtedly do not fall within the framework of the recommended European standards, the aim of

Hungary z 2011”, (CDL-AD(2012)001) and the Opinion „on the Cardinal Acts on the Judiciary that were amended following the adoption of Opinion CDL-AD(2012)001 on Hungary", (CDL$\mathrm{AD}(2012) 020)$.

${ }^{31}$ CDL-AD (2012)020 Opinion on the Cardinal Acts on the Judiciary that were amended following the adoption of Opinion CDL-AD(2012)001 on Hungary.

${ }^{32}$ CDL-AD(2012)020.

${ }_{33}$ Article 13 of the Fourth Amendment replaces Article 25.4 to 25.7 of the Fundamental Law. 
which is to de-politicize the courts. In the opinion of the Venice Commission, the fourth amendment to the Hungarian constitution is the result of an instrumental treatment of the constitution as a political tool of the government majority, and at the same time a clear signal of the blurring of the key difference between the process of constitutional changes and ordinary politics ${ }^{34}$.

7. Because of the role of judicial councils in the process of appointing judges, a question arises about the scope of the power and the nature of the state president's decisions in this process. Historically, in many countries, the right to appoint judges is a prerogative of the president of the state. Nowadays, however, the president usually acts on a motion. As a rule, in the past this was a motion of the Minister of Justice. Recently, to an increasing extent, this has been a motion of the judicial council. ${ }^{35}$ One of the problems is the issue of the nature of the council's motion and thus binding the president with a proposal made by the judicial council. The degree to which the president is free to appoint a judge and to which he is bound by the council's motion. The act of appointing a judge as a prerogative of the president is not subject to countersignature. However, it raises a question about the scope of the president's powers before the appointment deed is signed: whether the president is bound by a motion of the judicial council. Disputes concerning the scope of this right of the president are taking place in different countries and in some situations they are reflected in a specific legal regulation.

The evolution of legal solutions in this area is quite significant. Recently, one can observe tendencies to limit the president's right in this scope. For example, in the light of the amendments proposed to three acts on the courts in Romania ${ }^{36}$, the president has been completely excluded from the procedure for appointing and dismissing judges. The new legal proposals stipulate that the judicial council

${ }^{34}$ CDL-AD(2013)012.

${ }^{35}$ In Albania, e.g. upon the request of the High Council of Justice; in Armenia, upon recommendation of the Judicial Council; in the Czech Republic and Georgia on the basis of the proposal of the High Council of Justice; in Greece, on the basis of the decision of the Supreme Judicial Council; in Ireland; in Italy upon the proposal of the High Council of the Judiciary; in Lithuania upon the recommendation directed by a special institution of judges provided for in the Act. In Moldova on the basis of a proposal from the Superior Council of Magistrates; in Poland upon the request of the National Council of the Judiciary; in Romania on the basis of proposals of the Superior Council of Magistracy; in Slovakia on the basis of the proposal of the Judiciary Council.

${ }^{36}$ C.f. 3 draft acts in Romania on the status of judges and prosecutors (Act No 303/2004), on the organization of the judiciary (Act No 304/2004), on the Supreme Council of Judges (No 317/2004), CDL-AD (2018)007. 
is the only authority in the process of appointing judges. This is a rather uncompromising solution. The Venice Commission, by its very nature, has not been in favour of such a radical position. It has always recognized the role of the head of state in the process of appointing judges. However, owing to the appointment of judicial councils, the scope of this right has been significantly narrowed down. It is limited by the motion of the judicial council.

Therefore, in the current situation, in view of the role of these councils, it can be considered standard practice to bind the president to the council's motion. The president may or may not appoint a judge, but these must be special circumstances. The refusal to accede to the council's request should be of an exceptional nature. In such a case, however, the president cannot propose the candidate himself. The candidate must always be proposed by the judicial council. So far as the president is bound by the proposal of an independent judicial council, the appointment of judges by the president is not problematic. In this situation, one should support the view that the act of the president appointing a judge is to a large extent a protocol, symbolic act. Such an understanding of the president's appointment act is increasingly being referred to as a desirable European standard.

The Venice Commission, on the other hand, is very critical of the appointment of judges by parliament, considering that the act of appointing a judge of the common court should not be subject to a vote in parliament, as it cannot be ruled out that political considerations will outweigh the objective advantages of the candidate. This way of electing judges does not free the judiciary from political influence, but, on the contrary, introduces the whole procedure into the political debate and engages the judge in politics.

This argumentation is consistently repeated in subsequent opinions of the Venice Commission evaluating individual draft amendments to the constitution as well as the acts on the organization of courts and the status of judges. In a particular way, it was articulated in many opinions concerning the reform of the judiciary in Ukraine. This is because the Constitution of Ukraine stipulates that judges are appointed by the president for a specified period of time (5 years), and then, following this period, they are appointed on a permanent basis by parliament ${ }^{37}$. Such a solution triggered a critical review for two reasons: 1. appointment of judges for the so-called trial period, 2. the role of parliament in the process of appointing judges.

In its opinions, the Commission has consistently called for parliament to be deprived of the right to elect judges and for this right to be granted to the

37 Art. 128 of the Constitution of Ukraine of 1996 in: Constitution of Ukraine, Warsaw 1999. 
president, who is bound by the motion of the judicial council. This solution was considered to be in line with European standards ${ }^{38}$. As a result of constitutional amendments introduced in Ukraine in 2016, the Commission's comments have been taken into account. Parliament has been deprived of the right to elect judges as a step towards de-politicization and compliance with European standards. A similar reform was also undertaken by Montenegro in 2013. The Montenegrin parliament adopted constitutional amendments enhancing the independence of the judiciary in 2013. These amendments limited the role of parliament in the appointment procedure for judges. There are also countries which provide for a system of appointments of judges directly by the judicial councils. This is the case, for example, in Bulgaria and Croatia. However, it can be agreed that the system of nomination of judges by the judicial council itself is not, nevertheless, a European standard.

8. All the countries undergoing transformation were, and some still are, in a very difficult, not to say critical situation with regard to the degree of crime, and especially corruption associated with the transformation itself. European standards have been developed under the conditions of normally developing countries with stable democratic rules and constitutional customs; they have not been prepared for extreme situations, and this is the case in countries in transition, even twenty years afterwards. In this context, there is a very dangerous temptation to „loosen” these standards under the slogan of ensuring the effectiveness of the courts at the expense of their independence. In spite of membership of the Council of Europe and even of the European Union, one can observe a tendency, unfortunately not an isolated one, to return to such solutions in the internal order as pose a threat to the de-politicization of courts. Often, when negating European standards, the rhetoric of protecting national sovereignty is used.

Initially, it seemed that reservations on the part of the newly acceding countries would be triggered by the acceptance of a procedure for monitoring the compliance of the countries with European standards. These reservations on the monitoring procedure were based on two premises: 1) a sense of regained sovereignty and prevention of external interference from any side, 2) a still strong conviction that the issue of monitoring the observance of the law by the state in relation to its own citizens is only an internal state issue and not an external one. However, this seemed to be a phenomenon associated with the initial period of adaptation to standards. Unfortunately, it now turns out that it can be permanent and that such attitudes are, in fact, constantly present.

${ }^{38}$ CDL-AD (2013)014. 
It is this way of thinking that gives rise to discussions or even attacks on the role of the Venice Commission, as an external body that imposes certain solutions. This suggests a failure to understand the role of the Commission as a body providing legal assistance in the field of public law, with a consultative role to preserve common European values in the scope of guarantees of independent judiciary, values that are common not only to the entire organization, but also to the individual states that are members of this wider structure. There is a lack of understanding of the need to shape a constitutional culture, to separate constitutional issues from ordinary politics and to see the constitution as a commonly accepted framework for democratic processes ${ }^{39}$.

Giving in to pressure aimed at the weakening of standards is dangerous both for the entire community and for individual states. It is necessary to shape, precisely through a stable constitution, the attitudes of constitutionalism. There are strict interdependencies in this respect. A stable constitution undoubtedly has an impact on the development of attitudes of constitutionalism and thus on the understanding of the mechanisms rooted in the constitution, including the principles of separation of powers and independence of courts. Furthermore, formed attitudes of constitutionalism, expressed in the political culture, make it possible for society to react at a time of noticeable threats of an imbalance, dominance of one power over another, and especially the interference of the executive power in the judiciary.

\section{BIBLIOGRAPHY:}

Łętowska E., Łętowski J., Co wynika dla sąów z konstytucyjnej zasady podziału władz, [in:] Konstytucja i gwarancje jej przestrzegania. Ksiega pamiątkowa ku czci prof. J. Zakrzewskiej, Warszawa 1996.

Piotrowski R., Sędziowie i granice władzy demokratycznej w świetle Konstytucji RP, „Ruch Prawniczy, Ekonomiczny i Socjologiczny” 2018, z. 1.

Suchocka H., Kański L., Zmiany konstytucyjnej regulacji sqdownictwa i prokuratury dokonane w 1989 r., „Państwo i Prawo” 1991, z. 1.

Suchocka H., The separation of powers in the Polish Constitution, „Review of Central and East European Law" 2000, n. 3.

${ }^{39}$ CDL-AD(2011)016. 
